\title{
Vamorolone trial in Duchenne muscular dystrophy shows dose-related improvement of muscle function
}

Eric P. Hoffman, PhD, Benjamin D. Schwartz, MD, Laurel J. Mengle-Gaw, PhD, Edward C. Smith, MD, Diana Castro, MD, Jean K. Mah, MD, Craig M. McDonald, MD, Nancy L. Kuntz, MD, Richard S. Finkel, MD, Michela Guglieri, MD, Katharine Bushby, MD, Mar Tulinius, MD, Yoram Nevo, MD, Monique M. Ryan, MD, Richard Webster, MD, Andrea L. Smith, MS, Lauren P. Morgenroth, MS, Adrienne Arrieta, MS, Maya Shimony, MPH, Catherine Siener, PT, Mark Jaros, PhD, Phil Shale, PhD, John M. McCall, PhD, Kanneboyina Nagaraju, PhD, DVM, John van den Anker, MD, PhD, Laurie S. Conklin, MD, Avital Cnaan, PhD, Heather Gordish-Dressman, PhD, Jesse M. Damsker, PhD, and Paula R. Clemens, MD, and the Cooperative International Neuromuscular Research Group

Neurology ${ }^{\circledR}$ 2019;93:e1312-e1323. doi:10.1212/WNL.0000000000008168

\section{Abstract}

\section{Objective}

To study vamorolone, a first-in-class steroidal anti-inflammatory drug, in Duchenne muscular dystrophy (DMD).

\section{Methods}

An open-label, multiple-ascending-dose study of vamorolone was conducted in 48 boys with DMD (age 4-<7 years, steroid-naive). Dose levels were $0.25,0.75,2.0$, and $6.0 \mathrm{mg} / \mathrm{kg} / \mathrm{d}$ in an oral suspension formulation (12 boys per dose level; one-third to 10 times the glucocorticoid dose in DMD). The primary goal was to define optimal doses of vamorolone. The primary outcome for clinical efficacy was time to stand from supine velocity.

\section{Results}

Oral administration of vamorolone at all doses tested was safe and well tolerated over the 24-week treatment period. The $2.0-\mathrm{mg} / \mathrm{kg} / \mathrm{d}$ dose group met the primary efficacy outcome of improved muscle function (time to stand; 24 weeks of vamorolone treatment vs natural history controls), without evidence of most adverse effects of glucocorticoids. A biomarker of bone formation, osteocalcin, increased in vamorolone-treated boys, suggesting possible loss of bone morbidities seen with glucocorticoids. Biomarker outcomes for adrenal suppression and insulin resistance were also lower in vamorolone-treated patients with DMD relative to published studies of glucocorticoid therapy.

\section{Conclusions}

Daily vamorolone treatment suggested efficacy at doses of 2.0 and $6.0 \mathrm{mg} / \mathrm{kg} / \mathrm{d}$ in an exploratory 24-week open-label study.

\section{Classification of evidence}

This study provides Class IV evidence that for boys with DMD, vamorolone demonstrated possible efficacy compared to a natural history cohort of glucocorticoid-naive patients and appeared to be tolerated.

\author{
Correspondence \\ Dr. Hoffman \\ ericphoffman@gmail.com
}

\section{MORE ONLINE}

$\rightarrow$ Class of Evidence

Criteria for rating

therapeutic and diagnostic studies

NPub.org/coe

From ReveraGen Biopharma (E.P.H., J.M.M., K.N., J.v.d.A., L.S.C., J.M.D.), Rockville, MD; Binghamton University-SUNY (E.P.H., K.N.), NY: Camden Group (B.D.S., L.J.M.-G.), LLC, St. Louis, MO; Duke University (E.C.S.), Durham, NC; University of Texas Southwestern (D.C.), Dallas; Alberta Children's Hospital (I.K.M.), Calgary, Canada; University of California Davis (C.M.M.), Sacramento; Ann \& Robert H. Lurie Children's Hospital (N.L.K.), Chicago, IL; Nemours Children's Hospital (R.S.F.), Orlando, FL; John Walton Muscular Dystrophy Research Centre (M.G., K.B.), Newcastle University, Newcastle-Upon-Tyne, UK; Queen Silvia Children's Hospital (M.T.), Gothenburg, Sweden; Schneider Children's Medical Center (Y.N.), Tel Aviv University, Israel; Royal Children's Hospital and Murdoch Children's Research Institute (M.M.R.), Melbourne, Australia; The Children's Hospital at Westmead (R.W.), Sydney, Australia; TRiNDS LLC (A.L.S., L.P.M., A.A., M.S., C.S.), Kensington, MD; Summit Analytical (M.J., P.S.), Denver, CO; Children's National Health System (J.v.d.A., L.S.C., A.C., H.G.-D.), Washington, DC; and University of Pittsburgh and Department of Veterans Affairs Medical Center (P.R.C.), PA.

Go to Neurology.org/N for full disclosures. Funding information and disclosures deemed relevant by the authors, if any, are provided at the end of the article. 


\section{Glossary}

BMI = body mass index; CINRG = Cooperative International Neuromuscular Research Group; CTCAE $=$ Common Terminology Criteria for Adverse Events; DMD = Duchenne muscular dystrophy; DNHS = Duchenne Natural History Study; NF- $\mathrm{kB}=$ nuclear factor- $\mathrm{\kappa B}$; NSAA = North Star Ambulatory Assessment; SAE = serious adverse event; $6 \mathrm{MWT}=$ 6-minute walk test; TEAE = treatment-emergent adverse event; TTRW = time to run $/$ walk $10 \mathrm{~m}$; TTSTAND = timed stand from supine.

The potent anti-inflammatory efficacy of an adrenal steroid, 17-hydroxy-11-dehydrocorticosterone, was first reported in 14 patients with arthritis in $1949,{ }^{1}$ and the 1950 Nobel Prize in Physiology or Medicine was quickly awarded. ${ }^{2}$ Glucocorticoid treatment is effective for many inflammatory disorders; however, long-term treatment is associated with significant adverse effects. These are particularly problematic in the very young and the elderly.

Duchenne muscular dystrophy (DMD) is a progressive disorder caused by dystrophin deficiency in muscle. ${ }^{3}$ Glucocorticoids are the standard of care for DMD, delaying loss of ambulation caused by this condition for 2 to 4 years $^{4,5}$ Activation of the proinflammatory nuclear factor- $\mathrm{kB}$ (NF- $\mathrm{kB}$ ) pathway, the target of glucocorticoids, is seen soon after birth in muscle of patients with DMD. ${ }^{6,7}$

Vamorolone is a novel drug that appears to optimize traditional steroidal anti-inflammatory activities: transactivation (gene transcription via GRE-mediated binding of ligand/receptor dimers) is lost; transrepression (NF- $\mathrm{kB}$ inhibition anti-inflammatory activity) is retained; physiochemical membrane stabilization properties are improved; and mineralocorticoid receptor activity is changed from agonist to antagonist. ${ }^{8-13}$ Studies of vamorolone in animal models of chronic inflammatory states, including DMD mouse models, have shown retention of antiinflammatory efficacy and loss of adverse effects compared to prednisolone. ${ }^{10,12,14-16}$ The retention of antiinflammatory efficacy and loss of side effects in preclinical models are consistent with vamorolone blocking NF- $\mathrm{kB}-$ associated proinflammatory signals as a ligand/receptor monomeric state instead of the traditional molecular models of ligand/receptor dimeric complexes. ${ }^{17}$ A phase 1 study of vamorolone in healthy adult men ${ }^{18}$ and a 2 -week treatment, 2-week washout, 4-week phase 2 a study in patients with $\mathrm{DMD}^{19}$ showed an improved profile of typical glucocorticoid-like safety concerns as measured by serum biomarkers after 2 weeks of treatment. Vamorolone showed pharmacokinetics and metabolism similar to those of corticosteroids and is similarly administered with daily oral dosing. ${ }^{20}$ The 48 patients with DMD enrolled in the 4 week phase 2a study (VBP15-002) were then enrolled in a 24-week extension study (VBP15003) to test for drug efficacy, and the latter study is reported here.

\section{Methods}

\section{Study design and participants}

The primary research questions were to assess whether there was a dose-response relationship of orally administered vamorolone to improvement of gross motor strength and endurance through a dose-escalation study design and to assess the extent to which vamorolone has the pharmacodynamic safety concerns of glucocorticoids. The classification of level of evidence assigned to these questions was considered Class IV. Statistical adjustments for multiple testing (type 1 error) were not possible due to the multiple doses $(n=4)$ being tested and compared in a first-in-patient study of limited size and scope.

This open-label clinical trial included 2 sequential clinical trials involving the same 48 pediatric patients with $\mathrm{DMD}$. The first trial, VBP15-002, was a first-in-patient study using a traditional multiple-ascending-dose design, with the primary outcome of safety and toxicity. Participants were boys 4 to $<7$ years old diagnosed with DMD with molecular criteria (gene or protein studies) who had never been treated with glucocorticoids. Twelve patients were enrolled in each dose group, with 4 dose groups sequentially enrolled over a 24-fold dose range ( 0.25 , $0.75,2.0,6.0 \mathrm{mg} / \mathrm{kg} / \mathrm{d})(\mathrm{n}=48)$. Each dose group was monitored for safety, with each child treated with vamorolone for 2 weeks of daily treatment, followed by 2 weeks of washout (no drug treatment), before beginning recruitment into the next dose group. The findings of this initial multiple-ascending-dose study have been published. ${ }^{18}$ To fulfill the intent to treat required for clinical studies in children, all participants enrolled in VBP15-002 were subsequently enrolled in a 24-week extension phase at the same dose (VBP15-003). The results of VBP15003 are reported here. The clinical trials were designed with Food and Drug Administration advice (Investigational New Drug 11,8942) and European Medicines Agency guidance (EMEA-001794-PIP02-16).

The trials were designed with sample sizes needed to detect a glucocorticoid effect on timed function tests and change in body mass index (BMI) $z$ score by comparison with steroidnaive patients enrolled in the Cooperative International Neuromuscular Research Group (CINRG) Duchenne Natural History Study (DNHS; NCT00468832) $)^{5,21}$ and a CINRG clinical trial of prednisone $(0.75 \mathrm{mg} / \mathrm{kg} / \mathrm{d})$ $(\mathrm{NCT} 00110669)^{22}$ using a similar age range $(4-<8$ years). Comparison of 12- and 24-week changes in CINRG DNHS steroid-naive patients $(n=25)$ vs CINRG prednisone-treated 
boys $(n=13-28)$ suggested that group sizes of $\approx 12$ patients per dose group would be sufficient to detect improvements in timed function tests (efficacy outcomes) and increases in BMI $z$ score (safety outcome), assuming that vamorolone treatment would show the same effects on efficacy and safety as prednisone treatment (supplemental table 1 available from Dryad, doi.org/10.5061/dryad.1rd4hc7). Although the comparator studies provided the best available controlled evidence for study design, their use was limited to provision of an approximate guide for study design because they were conducted $>10$ years ago.

Ethics approval was obtained at each site. Patients were recruited at CINRG sites in the United States (5 sites), Canada (1 site), Australia (2 sites), Israel (1 site), Sweden (1 site), and the United Kingdom (1 site) over a 13-month enrollment period (July 2016-August 2017). After informed consent was obtained, 55 patients were screened, of whom 7 patients failed screening and were excluded from the study for 1 or more of the following reasons: lack of evidence of varicella immunity (2), inability to comply with study procedures (5), no confirmed diagnosis of DMD (1), and inability to complete the timed stand from supine (TTSTAND) test without assistance (1).

\section{Procedures}

Vamorolone was supplied as a $4 \%$ weight/volume citrusflavored suspension administered orally by volumetric syringe once daily in the morning. Dosing was followed by consumption of a $240-\mathrm{mL}$ glass of full-fat milk or fat equivalent because vamorolone absorption is increased by high-fat food. ${ }^{17}$ The first treatment period (VBP15-002; 2 weeks on drug, 2 weeks washout) has been described in detail elsewhere. ${ }^{18}$ At the week 4 visit of VBP15-002, patients were reconsented for VBP15-003, with the last visit of VBP15-002 coinciding with the first visit of VBP15-003 and daily drug treatment then continuing at the same dose for the patients who agreed to participate in the VBP15-003 study.

Procedures at screening (VBP15-002) and at weeks 4, 8, 16, and 24 (VBP15-003) included physical examination (including standard eye and integumentary evaluation), blood for laboratory investigations, and a 12-lead ECG. Timed function tests, ${ }^{23}$ 6-minute walk test (6MWT), ${ }^{24}$ and North Star Ambulatory Assessment (NSAA) ${ }^{25}$ were conducted by trained clinical evaluators according to CINRG standard operating procedures. ${ }^{5}$ Timed function tests were done at screening, at baseline (VBP15-002), and at weeks 12 and 24 (VBP15-003). Blood draws for fasting insulin and glucose measures and pharmacodynamic biomarker assessments were done periodically throughout VBP15-003. Adverse events were monitored throughout the study.

\section{Outcomes}

Reliability of timed function test outcomes was tested using 4 visits occurring over $\approx 6$ weeks in VBP15-002 (screening, baseline, week 2 [on drug], and week 4 [washout]) (4 repeated measures in each of 48 patients; supplemental table 2 available from Dryad, doi.org/10.5061/dryad.1rd4hc7). ${ }^{18}$ Calculation of precision using percentage coefficient of variance averaged for 48 boys with DMD enrolled in the VBP15-002 trial showed time to run/walk $10 \mathrm{~m}$ (TTRW), $6 \mathrm{MWT}$, and NSAA to be highly reliable outcomes (percentage coefficient of variance <30) in this DMD population.

Additional safety outcomes included blood chemistry panels and adverse event reporting. Glucocorticoid adverse effects were monitored with pharmacodynamic biomarkers used as proxy for (bridged to) later clinical morbidities (bone turnover markers [osteocalcin, type I collagen C-telopeptides, and procollagen $1 \mathrm{~N}$-terminal propeptide], adrenal suppression [first-in-morning serum cortisol], and insulin resistance [fasting serum insulin and glucose]).

\section{Statistical analyses}

For comparison of treatment groups for efficacy to external comparator (CINRG DNHS) and internal to the vamorolone trial, mixed-model repeated measures were used (baseline [VBP15-002], 12 and 24 weeks ([VBP15-003]) adjusted for age. The baseline assessment from VBP15-002 was used for change from baseline calculations. Assessments of efficacy were done by comparison of vamorolone treatment groups to an external comparator of steroid-naive patients (CINRG DNHS). ${ }^{5}$ Assessment of safety (change in BMI) was done by comparison of vamorolone treatment groups to an external comparator of prednisone-treated patients from a randomized, controlled trial (CINRG prednisone clinical trial). ${ }^{22} \mathrm{~A}$ prospective, randomized, controlled double-blind study that is underway will directly compare the efficacy and safety of vamorolone to prednisone (NCT03439670). All comparisons were limited to patients 4 to $<7$ years of age (same inclusion criteria).

\section{Classification of evidence}

This interventional study provides Class IV evidence that vamorolone at a dose of 2.0 or $6.0 \mathrm{mg} / \mathrm{kg} / \mathrm{d}$ improves muscle function over a 24-week treatment period in patients with DMD (age $4-<7$ years).

\section{Standard protocol approvals, registrations, and patient consents}

The clinical trials described (VBP15-002; VBP15-003) were approved by ethics standards committees on human experimentation (institutional and regional). Written informed consent was obtained from all participants (or guardians of participants) in the study (consent for research). The studies were registered with clinicaltrials.gov (NCT02760264, NCT02760277).

\section{Data availability}

Summarized data for key efficacy and safety outcomes will be posted on clinicaltrials.gov. 


\section{Results}

\section{Analysis of efficacy}

Baseline characteristics for the 4 ascending-dose groups and the external CINRG DNHS comparator (steroid naive and prednisone treated) are shown in table 1 . All comparisons to external comparators were limited to patients age 4 to $<7$ years (same inclusion criteria as the vamorolone trial). Two patients withdrew from the vamorolone study for reasons unrelated to vamorolone treatment ( 1 taking $0.25 \mathrm{mg} / \mathrm{kg} / \mathrm{d}, 1$ taking $6.0 \mathrm{mg} / \mathrm{kg} / \mathrm{d}$ ).

The primary efficacy endpoint was TTSTAND velocity (rises per second) change from VBP15-002 baseline to VBP15-003 week 24 for the vamorolone group compared to the untreated DNHS control group. Mean changes from baseline to weeks 12 and 24 showed dose- and time-related increases, with greater increases observed for the $2.0-$ and $6.0-\mathrm{mg} / \mathrm{kg} /$ $\mathrm{d}$ groups and greater increases at week 24 compared to week 12 (figure 1, table 2, and supplemental table 3 available from Dryad, doi.org/10.5061/dryad.1rd4hc7). The mean difference in change from baseline to week 24 was significant for comparison of the $2.0-\mathrm{mg} / \mathrm{kg} / \mathrm{d}$ group to the untreated DNHS cohort $(p=0.04)$. The mean difference in change from baseline to week 24 was also significant for the comparison of the $2.0-$ and $6.0-\mathrm{mg} / \mathrm{kg} / \mathrm{d}$ groups to the $0.25-\mathrm{mg} /$ $\mathrm{kg} / \mathrm{d}$ group ( $p=0.02$ and $p=0.04$, respectively).

TTRW velocity mean changes from baseline to weeks 12 and 24 (meters per second; secondary outcome) showed doserelated increases, with greater increases observed for the $2.0-$ and $6.0-\mathrm{mg} / \mathrm{kg} / \mathrm{d}$ vamorolone groups (figure 2 , table 2 , and supplemental table 4 available from Dryad (doi.org/10. 5061/dryad.1rd4hc7). The mean changes from baseline for each vamorolone group were similar at weeks 12 and 24 . The mean differences in change from baseline to week 12 and to week 24 were significant for comparison of the $6.0-\mathrm{mg} / \mathrm{kg} /$ $\mathrm{d}$ group to the untreated DNHS cohort $(p=0.01$ and $p=0.003$, respectively). The mean differences in change from baseline to weeks 12 and 24 were also significant for the comparison of the $6.0-$ and $0.25-\mathrm{mg} / \mathrm{kg} / \mathrm{d}$ groups $(p=0.01$ and $p=0.006$, respectively).

For the 6MWT (secondary outcome), mean meters walked increased at week 12 compared to baseline for all vamorolone groups, and at week 24 for the $0.75-, 2.0-$, and $6.0-\mathrm{mg} / \mathrm{kg} /$ d groups, the improvement correlated with increases in dose level (figure 3, table 2, and supplemental table 5 available from Dryad, doi.org/10.5061/dryad.1rd4hc7,). The mean difference in change from baseline to week 24 was significant for the $2.0-$ and $6.0-\mathrm{mg} / \mathrm{kg} / \mathrm{d}$ groups compared to the $0.25-\mathrm{mg} /$ $\mathrm{kg} / \mathrm{d}$ group ( $p=0.01$ and $p=0.002$, respectively).

Time to climb 4 stairs velocity mean changes from baseline to week 24 (tasks per second; secondary outcome) showed dose-related changes, with increases observed for the 2.0- and $6.0-\mathrm{mg} / \mathrm{kg} / \mathrm{d}$ groups (figure 4, table 2, and supplemental table 6 available from Dryad, doi.org/10.5061/dryad.1rd4hc7). None of the mean differences in change from baseline to week 24 comparing each vamorolone group to the untreated DNHS cohort and to each other were significant $(p>0.05$ for all comparisons).

The NSAA (0-34-point ordinal scale; secondary outcome) showed greater increases in the $2.0-$ and $6.0-\mathrm{mg} / \mathrm{kg} / \mathrm{d}$ groups at 24 weeks with a magnitude of improvement between 2 and 2.5 points compared to baseline (supplemental figure 1 available from Dryad, doi.org/10.5061/dryad.1rd4hc7). CINRG DNHS data were not available for this outcome, and mixed-model repeated measures comparing vamorolone dose groups were not significant.

\section{Analysis of safety}

\section{Adverse events}

Treatment-emergent adverse events (TEAEs) were reported with similar incidence by patients in all 4 vamorolone groups (TEAE by System Organ Class and Preferred Term in supplemental

Table 1 Baseline characteristics

\begin{tabular}{|c|c|c|c|c|c|c|c|c|}
\hline & No. & Age y & $\mathrm{BMI}, \mathrm{kg} / \mathrm{m}^{2}$ & TTSTAND, s & TTRW s & 6MWT, m & NSAA score & TTCLIMB, s \\
\hline $0.25 \mathrm{mg} / \mathrm{kg} / \mathrm{d}$ & 12 & $5.2 \pm 1.0$ & $17.4 \pm 1.1$ & $6.1 \pm 2.1$ & $6.5 \pm 1.4$ & $316 \pm 59$ & $19.0 \pm 5.1$ & $5.4 \pm 1.5$ \\
\hline $0.75 \mathrm{mg} / \mathrm{kg} / \mathrm{d}$ & 12 & $4.8 \pm 0.8$ & $16.5 \pm 1.5$ & $5.1 \pm 2.3$ & $5.9 \pm 1.2$ & $331 \pm 53$ & $20.5 \pm 5.6$ & $4.6 \pm 2.8$ \\
\hline $2.0 \mathrm{mg} / \mathrm{kg} / \mathrm{d}$ & 12 & $4.7 \pm 0.9$ & $17.2 \pm 0.8$ & $5.3 \pm 2.0$ & $5.6 \pm 1.1$ & $354 \pm 65$ & $20.0 \pm 4.9$ & $4.6 \pm 2.8$ \\
\hline $6.0 \mathrm{mg} / \mathrm{kg} / \mathrm{d}$ & 12 & $4.8 \pm 0.8$ & $16.5 \pm 1.0$ & $5.9 \pm 2.8$ & $6.3 \pm 1.2$ & $337 \pm 63$ & $19.7 \pm 4.9$ & $5.0 \pm 2.4$ \\
\hline All vamorolone groups & 48 & $4.9 \pm 0.9$ & $16.9 \pm 1.2$ & $5.6 \pm 2.3$ & $6.1 \pm 1.2$ & $334 \pm 59$ & $19.8 \pm 5.0$ & $4.9 \pm 2.4$ \\
\hline CINRG DNHS steroid naive & 31 & $4.9 \pm 0.8$ & $15.2 \pm 1.6$ & $5.9 \pm 3.2$ & $6.6 \pm 2.0$ & na & na & $6.3 \pm 4.1$ \\
\hline CINRG prednisone treated & 14 & $5.7 \pm 0.7$ & $16.3 \pm 1.7$ & $10.03 \pm 12.1$ & $6.2 \pm 2.4$ & na & na & $6.1 \pm 5.7$ \\
\hline
\end{tabular}

Abbreviations: BMI = body mass index; CINRG = Cooperative International Neuromuscular Research Group; DNHS = Duchenne Natural History Study; NSAA = North Star Ambulatory Assessment; 6MWT = 6-minute walk test; TTCLIMB = time to climb 4 stairs; TTRW = time to run/walk 10 m; TTSTAND = timed stand from supine.

All values are mean \pm SD. 


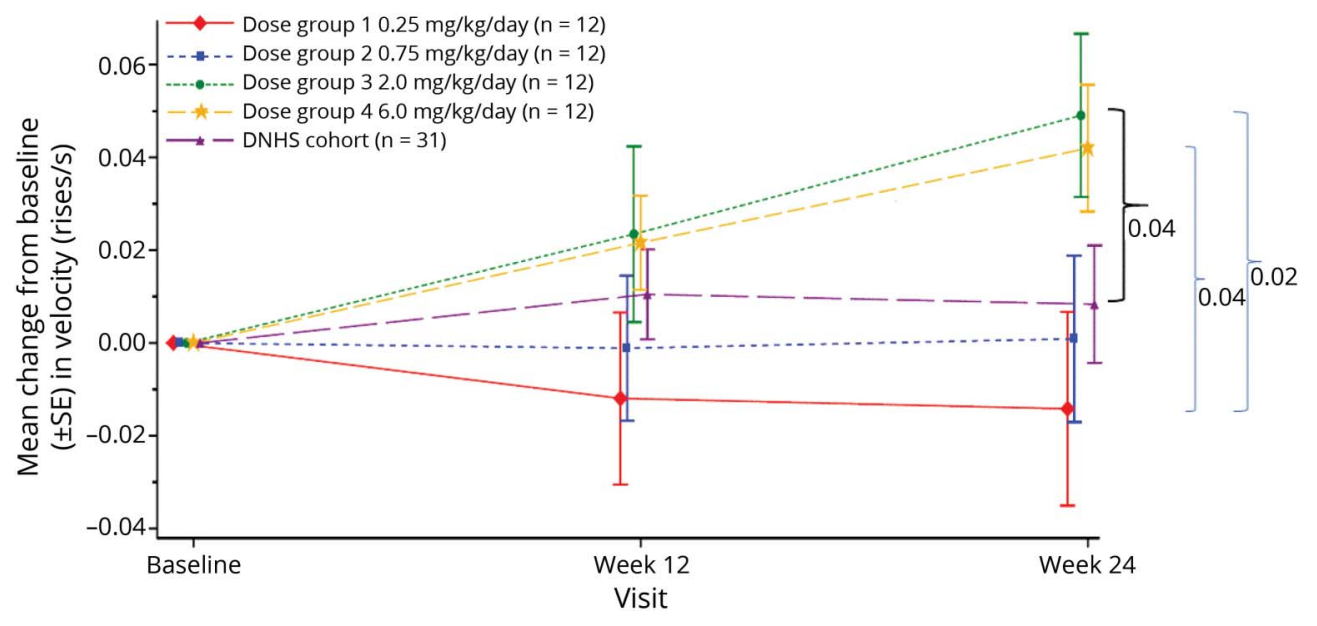

Brackets indicate mixed-model repeated-measures $p$ values (black for comparisons to Cooperative International Neuromuscular Research Group Duchenne Natural History Study [DNHS] external comparator; blue for within-trial dose group comparisons). table 7 available from Dryad, doi.org/10.5061/dryad.1rd4hc7; TEAEs by most frequent preferred safety term in supplemental table 8 available from Dryad). Several TEAEs commonly observed with long-term glucocorticoid therapy were observed only in the $2.0-\mathrm{mg} / \mathrm{kg} / \mathrm{d}$ group (abnormal behavior; 1 patient) or $6.0-\mathrm{mg} / \mathrm{kg} / \mathrm{d}$ group (hypertrichosis [2 patients], anxiety, abnormal blood cortisol level, cushingoid habitus, and personality change [1 patient each]). The other reported TEAEs did not exhibit a dose-related incidence.

The majority of TEAEs reported across the 4 vamorolone groups were considered by the site investigators to be mild (Common Terminology Criteria for Adverse Events [CTCAE] grade 1) or moderate (CTCAE grade 2) in severity. Sixteen patients experienced TEAEs considered to be moderate in severity: 3 patients (25.0\%), 3 patients $(25.0 \%), 4$ patients $(33.3 \%)$, and 6 patients $(50.0 \%)$ in the $0.25-, 0.75-$, $2.0-$, and $6.0-/ \mathrm{kg} / \mathrm{d}$ groups, respectively. Two patients $(18 \%)$ in the $6.0-\mathrm{mg} / \mathrm{kg} / \mathrm{d}$ group experienced TEAEs considered to be severe (CTCAE grade 3 ) but determined to be unrelated to vamorolone therapy.

A total of 12 patients experienced at least 1 TEAE during the study: 1 patient (8.3\%), 2 patients (16.7\%), 4 patients (33.3\%), and 5 patients $(41.7 \%)$ in the $0.25-, 0.75-, 2.0-$, and $6.0-\mathrm{mg} / \mathrm{kg} / \mathrm{d}$ groups, respectively. None of the TEAEs was serious or severe (CTCAE grade $\geq 3$ ). No deaths were reported during the study.

One patient in the $0.75-\mathrm{mg} / \mathrm{kg} / \mathrm{d}$ group and 2 patients in the $6.0-\mathrm{mg} / \mathrm{kg} / \mathrm{d}$ group experienced a total of 4 treatmentemergent serious adverse events (SAEs) during the study. One patient in the $0.75-\mathrm{mg} / \mathrm{kg} / \mathrm{d}$ group experienced a moderate (CTCAE grade 2) treatment-emergent SAE of pneumonia; in the $6.0-\mathrm{mg} / \mathrm{kg} / \mathrm{d}$ group, 1 patient experienced a severe (CTCAE grade 3) treatment-emergent SAE of dehydration, and a second patient experienced severe (CTCAE grade 3) treatment-emergent SAEs of testicular torsion and hypoxia. No SAEs were considered by the investigator to be related to study drug; all resolved during essentially uninterrupted study participation.

No patient in any dose level group experienced a TEAE leading to study drug or study discontinuation.

\section{Clinical laboratory results}

Mean changes from VBP15-002 baseline to the VBP15-003 weeks 4, 8, 16, and 24 assessment time points in all hematology parameters were generally minimal, similar among the 4 dose level groups, and clinically unremarkable. No dose-related changes in mean changes were observed for any of the hematology parameters.

Mean changes from VBP15-002 baseline to the VBP15-003 weeks $4,8,16$, and 24 assessment time points in all chemistry parameters were minimal and similar among the 4 vamorolone groups; no dose-related mean changes were observed. The 4 enzymes alanine transaminase, aspartate transaminase, creatine kinase, and lactate dehydrogenase are all found in muscle and are elevated significantly above the upper limit of the normal range in patients with DMD.

Glutamate dehydrogenase and $\gamma$-glutamyltransferase are liver-preferential enzymes monitored in this study to assess potential drug-induced liver injury. None of the mean changes in glutamate dehydrogenase from VBP15-002 baseline to any of the VBP15-003 on-treatment assessment time points were significant for any vamorolone group. All remained at or below the normal range.

\section{Change in BMI $z$ score}

Mean changes in BMI $z$ score from VBP15-002 baseline to VBP15-003 weeks 12 and 24 showed dose- and time-related increases, with greater increases observed for the 2.0- and 
Table 2 Effect of vamorolone on patient motor function tests and body mass index

\section{Week 24 change from baseline}

Group 1, Group 2,

$0.25 \mathrm{mg} / \mathrm{kg} / \mathrm{d}$

Group 2, Group 3,

$(n=12)$

$(n=12) \quad(n=12) \quad(n=12)$

$2.0 \mathrm{mg} / \mathrm{kg} / \mathrm{d}$

$(n=12) \quad(n=12) \quad(n=12)$

Group 4,

$6.0 \mathrm{mg} / \mathrm{kg} / \mathrm{d}$

CINRG

DNHS $^{\mathrm{a}}$

$(n=31)$

TTSTAND

\begin{tabular}{|c|c|c|c|c|c|}
\hline No. & 10 & 12 & 12 & 11 & 29 \\
\hline Mean & -0.01 & 0.00 & 0.05 & 0.04 & 0.01 \\
\hline SD & 0.066 & 0.062 & 0.061 & 0.045 & 0.068 \\
\hline MMRM $p$ value vs DNHS & 0.4062 & 0.9554 & 0.0397 & 0.1048 & \\
\hline MMRM $p$ value vs group 1 & & 0.5067 & 0.0192 & 0.0442 & \\
\hline \multicolumn{6}{|l|}{ TTRW } \\
\hline No. & 12 & 12 & 12 & 11 & 30 \\
\hline Mean & -0.05 & 0.06 & 0.06 & 0.27 & -0.01 \\
\hline SD & 0.311 & 0.210 & 0.210 & 0.254 & 0.256 \\
\hline MMRM $p$ value vs DNHS & 0.7248 & 0.3768 & 0.3500 & 0.0035 & \\
\hline MMRM $p$ value vs group 1 & & 0.3082 & 0.2895 & 0.0059 & \\
\hline \multicolumn{6}{|l|}{ 6MWT } \\
\hline No. & 10 & 12 & 10 & 9 & \\
\hline Mean & -11.6 & 18.9 & 29.2 & 43.9 & \\
\hline SD & 29.45 & 41.08 & 35.91 & 43.72 & \\
\hline MMRM $p$ value vs group 1 & & 0.0644 & 0.0153 & 0.0019 & \\
\hline TTCLIMB & 12 & 12 & 12 & 11 & 31 \\
\hline \multicolumn{6}{|l|}{ No. } \\
\hline Mean & 0.00 & 0.01 & 0.04 & 0.05 & 0.01 \\
\hline SD & 0.076 & 0.066 & 0.090 & 0.061 & 0.062 \\
\hline MMRM $p$ value vs DNHS & 0.8532 & 0.6581 & 0.0811 & 0.0507 & \\
\hline \multicolumn{2}{|l|}{ MMRM $p$ value vs group 1} & 0.6107 & 0.1180 & 0.0747 & \\
\hline & \multicolumn{5}{|c|}{ Week 24 change from baseline } \\
\hline BMI z score & $\begin{array}{l}\text { Group } 1 \\
0.25 \mathrm{mg} / \mathrm{kg} / \mathrm{d} \\
(\mathrm{N}=12)\end{array}$ & $\begin{array}{l}\text { Group } 2 \\
0.75 \mathrm{mg} / \mathrm{kg} / \mathrm{d} \\
(\mathrm{N}=12)\end{array}$ & $\begin{array}{l}\text { Group } 3 \\
2.0 \mathrm{mg} / \mathrm{kg} / \mathrm{d} \\
(\mathrm{N}=12)\end{array}$ & $\begin{array}{l}\text { Group } 4 \\
6.0 \mathrm{mg} / \mathrm{kg} / \mathrm{d} \\
(\mathrm{N}=12)\end{array}$ & $\begin{array}{l}\text { CINRG } \\
\text { prednisone }\end{array}$ \\
\hline No. & 12 & 12 & 12 & 11 & 13 \\
\hline Mean & -0.161 & -0.210 & 0.043 & 0.493 & 0.543 \\
\hline SD & 0.3234 & 0.3629 & 0.3849 & 0.6363 & 0.6646 \\
\hline MMRM $p$ value vs prednisone & 0.0037 & 0.0003 & 0.0612 & 0.9261 & \\
\hline MMRM $p$ value vs group 1 & & 0.4697 & 0.2680 & 0.0035 & \\
\hline
\end{tabular}

Abbreviations: $\mathrm{BL}=$ baseline; $\mathrm{BMI}=$ body mass index; $\mathrm{CINRG}=$ Cooperative International Neuromuscular Research Group; DNHS = Duchenne Natural History Study; MMRM = mixed-model repeated-measures; $6 \mathrm{MWT}$ = 6-minute walk test; TTCLIMB = time to climb 4 stairs; TTRW = time to run/walk $10 \mathrm{~m}$; TTSTAND = timed stand from supine.

a Baseline DNHS, week 12 DNHS, week 24 DNHS, and change from baseline DNHS are presented.

${ }^{\mathrm{b}}$ Baseline CINRG prednisone cohort, week 12 CINRG prednisone cohort, week 24 CINRG prednisone cohort, and change from baseline CINRG prednisone cohort are presented. 


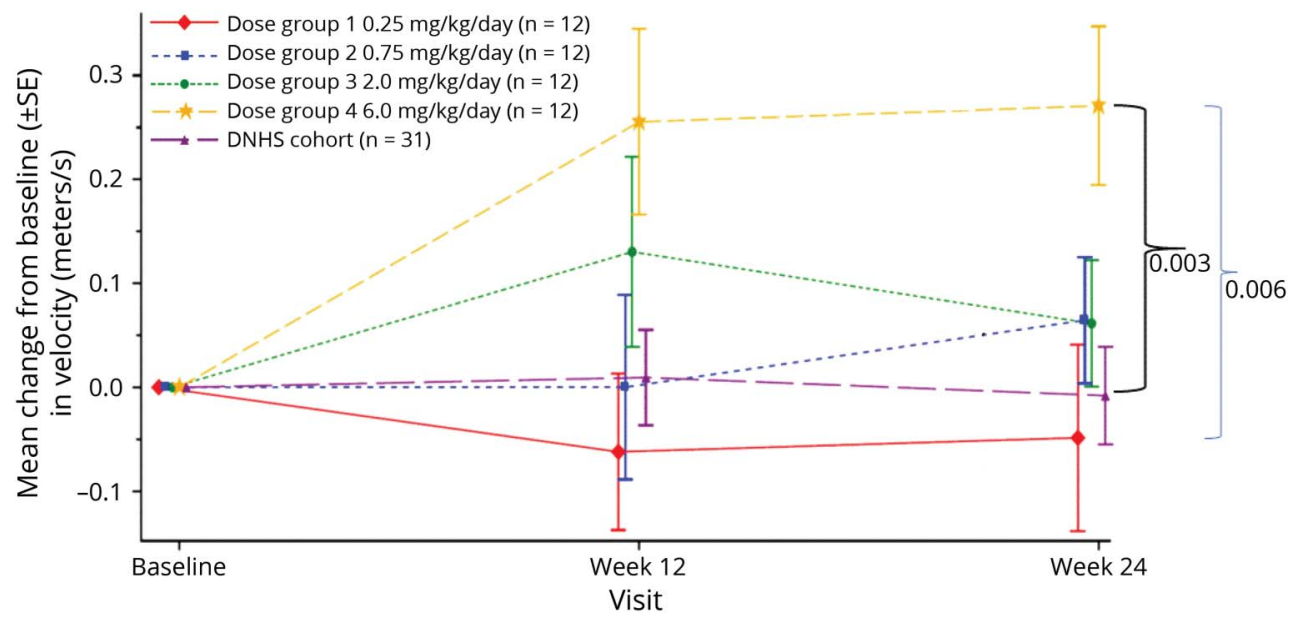

Brackets indicate mixed-model repeated-measures $p$ values (black for comparisons to Cooperative International Neuromuscular Research Group Duchenne Natural History Study [DNHS] external comparator; blue for within-trial dose group comparisons).

$6.0-\mathrm{mg} / \mathrm{kg} / \mathrm{d}$ groups and greater increases at week 24 compared to week 12 for the $6.0-\mathrm{mg} / \mathrm{kg} / \mathrm{d}$ group (figure 5 and supplemental table 9 available from Dryad, doi.org/10. $5061 /$ dryad.1rd4hc7). The mean difference in change from baseline to week 24 was significant for comparison of the 0 . $25-$ and $0.75-\mathrm{mg} / \mathrm{kg} / \mathrm{d}$ groups to the prednisone-treated cohort ( $p=0.0037$ and $p=0.0003$, respectively) but was not significant for comparison of the $2.0-$ and $6.0-\mathrm{mg} / \mathrm{kg} /$ d groups to the prednisone cohort.

\section{Pharmacodynamic serum biomarkers}

Osteocalcin and procollagen type I propeptides are measures of bone formation (decreases with glucocorticoid treatment), and C-terminal telopeptide is a measure of bone resorption (increases with glucocorticoid treatment). Osteocalcin mean change from VBP15-002 baseline to VBP15-003 assessment time points consistently showed increases in the $0.75-$ and $2.0-\mathrm{mg} / \mathrm{kg} / \mathrm{d}$ groups at all assessment time points (supplemental table 10 available from Dryad, doi.org/10.5061/ dryad.1rd4hc7). The mean increases from VBP15-002 baseline to VBP15-003 week 24 for the $0.75-$ and $2.0-\mathrm{mg} / \mathrm{kg} / \mathrm{d}$ groups were significant ( $p=0.0002$ and $p=0.0004$, respectively). The mean increase from VBP15-002 baseline to VBP15-003 week 24 for the $6.0-\mathrm{mg} / \mathrm{kg} / \mathrm{d}$ group was not significant $(p=0.0621)$. The mean $( \pm S D)$ change from VBP15-002 baseline to VBP15-003 assessment time points in procollagen type I propeptides levels showed increases for the 0.75-, 2.0-, and $6.0-\mathrm{mg} / \mathrm{kg} / \mathrm{d}$ groups at week 24 (supplemental table 10 available from Dryad). The mean $( \pm S D)$ change from VBP15002 baseline to VBP15-003 assessment time points in C-terminal telopeptide levels showed time-related progressive increases for the $2.0-$ and $6.0-\mathrm{mg} / \mathrm{kg} / \mathrm{d}$ dose level groups at the VBP15-003 assessment time points (supplemental table 11 available from Dryad). The mean increases from VBP15-002

Figure 3 Six-minute walk test mean $( \pm \mathrm{SE})$ change from baseline

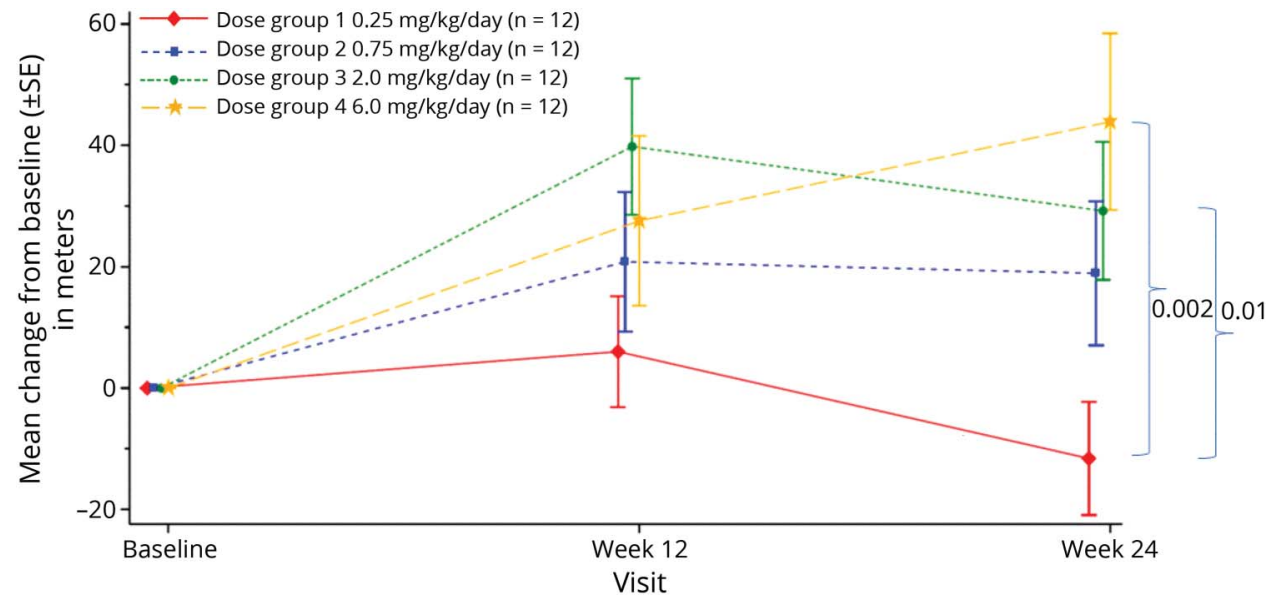

Brackets indicate mixed-model repeated-measures $p$ values (withintrial dose group comparisons). 


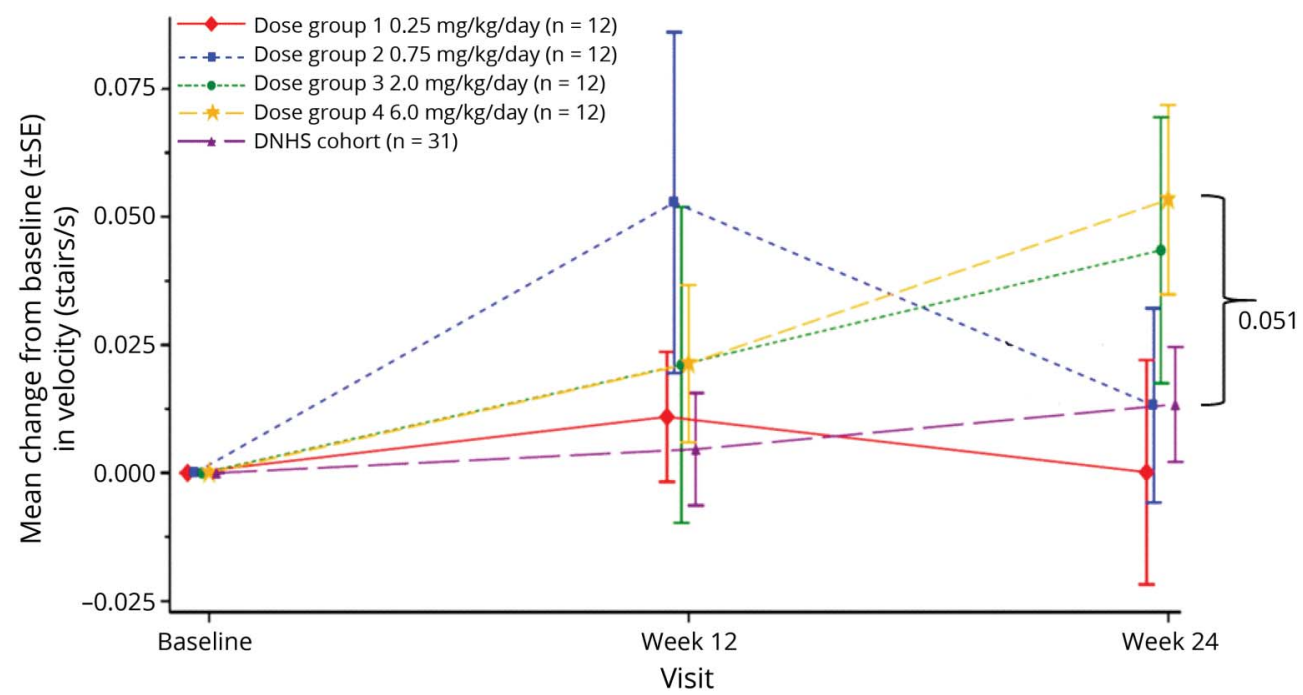

Brackets indicate mixed-model repeated-measures $p$ values (black for comparisons to Cooperative International Neuromuscular Research Group Duchenne Natural History Study [DNHS] external comparator). baseline to VBP15-003 week 24 were significant for the $0.75-$, $2.0-$, and $6.0-\mathrm{mg} / \mathrm{kg} / \mathrm{d}$ groups $(p=0.028, p=0.008$, and $p=$ 0.004 , respectively).

For assessment of adrenal suppression, morning cortisol levels (drawn before noon) at the VBP15-003 week 24 assessment time point showed that 0 of 8 tested patients $(0.25$ $\mathrm{mg} / \mathrm{kg} / \mathrm{d}), 1$ of $12(8.3 \%)$ tested patients $(0.75 \mathrm{mg} / \mathrm{kg} / \mathrm{d}), 5$ of $12(41.7 \%)$ tested patients $(2.0 \mathrm{mg} / \mathrm{kg} / \mathrm{d})$, and 8 of 9 $(88.9 \%)$ tested patients $(6.0 \mathrm{mg} / \mathrm{kg} / \mathrm{d})$ had significantly reduced levels $(<3.6 \mu \mathrm{g} / \mathrm{dL}[100 \mathrm{nmol} / \mathrm{L}])$, consistent with long-term adrenal suppression (supplemental table 12 available from Dryad, doi.org/10.5061/dryad.1rd4hc7). Dose-responsive decreases in adrenocorticotropic hormone were observed throughout the study although not controlled for time of day (supplemental table 12 available from Dryad).

Mean changes in fasting glucose from VBP15-002 baseline to VBP15-003 weeks 12 and 24 were clinically unremarkable for all vamorolone groups, although significant decreases were observed at week 24 for the 2.0- and $6.0-\mathrm{mg} / \mathrm{kg} / \mathrm{d}$ dose level groups (supplemental table 13 available from Dryad, doi.org/10.5061/dryad.1rd4hc7). Fasting insulin mean changes from VBP15-002 baseline showed dose-related increases at week 24, with significance observed for the $6.0-\mathrm{mg} / \mathrm{kg} / \mathrm{d}$ dose level group at weeks 12 $(p=0.0015)$ and $24(p=0.0237)$ (supplemental table 13 available from Dryad). No significant changes in hemoglobin $A_{1 c}$ were seen at any dose or time point compared to

Figure 5 Body mass index (BMI) z score mean ( \pm SE) change from baseline (safety population)

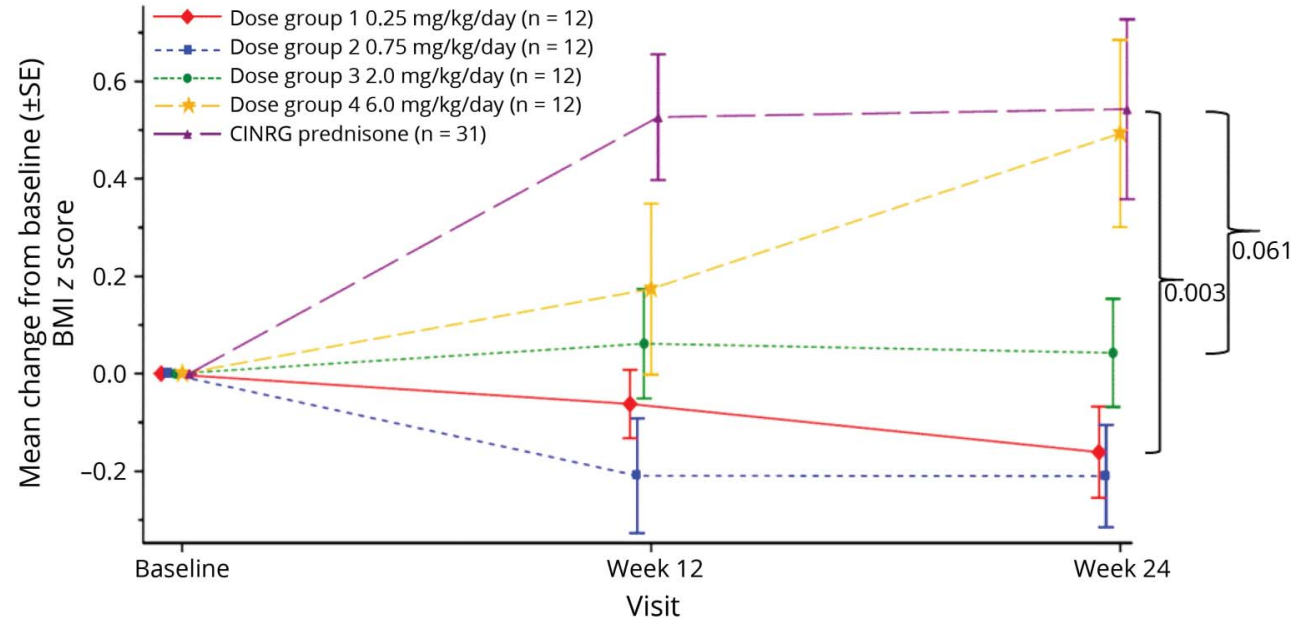

Brackets indicate mixed-model repeated-measures $p$ values (comparisons to Cooperative International Neuromuscular Research Group [CINRG] prednisone trial external comparator). 
baseline, and no patient had a hemoglobin $A_{1 c}$ level above the normal range $(6.0 \%)$.

\section{Discussion}

Vamorolone was well tolerated in patients with DMD 4 to $<7$ years of age, with no adverse events leading to reduction of drug dosing or withdrawal from the trial. All SAEs were assessed as either unrelated or remotely related to study medication by both the investigators and sponsor; no action was taken with study medication beyond brief interruption.

The TTSTAND primary outcome measure in vamorolonetreated patients with DMD supports efficacy of the $2.0-\mathrm{mg}$ / $\mathrm{kg} / \mathrm{d}$ dose group ( $\approx 3$ times the prednisone dose of $0.75 \mathrm{mg}$ / $\mathrm{kg} / \mathrm{d}$ for DMD) at 24 weeks (figure 1 and table 2) and for the secondary outcome measure of 6MWT at both 12 and 24 weeks of treatment (figure 2). The $2.0-\mathrm{mg} / \mathrm{kg} / \mathrm{d}$ dose showed superior clinical safety to prednisone-treated external comparators with less weight gain (figure 4) and improvement of bone turnover and insulin resistance biomarkers. There was evidence of adrenal suppression in a subset of boys with DMD treated with $2.0 \mathrm{mg} / \mathrm{kg} / \mathrm{d}$ vamorolone, with $18 \%$ of patients showing reduced morning cortisol levels. Future studies of vamorolone will include adrenocorticotropic hormone-challenge tests to further explore adrenal function.

The highest dose of vamorolone tested, $6.0 \mathrm{mg} / \mathrm{kg} / \mathrm{d}$ ( $\approx 9$ times the prednisone dose in DMD), showed greater improvements in 6MWT (figure 2) and TTRW (figure 3). However, this dose also showed more safety concerns than the $2.0-\mathrm{mg} / \mathrm{kg} / \mathrm{d}$ dose, with a mean increase in BMI $z$ score similar to that with prednisone (figure 4), increased incidence of adrenal suppression as measured by morning cortisol ( $88.9 \%$ of patients after 24 weeks of treatment), and mild increases of serum insulin possibly due to increased insulin resistance.

A longitudinal study of 440 boys with DMD in the CINRG DNHS defined 5 milestone groups based on TTSTAND findings at a young age that were predictive of later time of loss of clinically meaningful milestones closely linked to quality-oflife measures. ${ }^{5}$ Average improvement of the $2.0-\mathrm{mg} / \mathrm{kg} / \mathrm{d}$ vamorolone dose group was from 5.3 seconds (baseline) to 4.2 seconds ( 24 weeks of treatment). This corresponds to a transition from milestone group 2 (likely to experience decline in function and possibly loss of standing ability) to milestone group 1 (patients likely to show stability or improvement), suggesting that vamorolone-related improvements in the primary outcome measure may be clinically meaningful.

The 6MWT showed a clinically meaningful and significant vamorolone treatment effect of $>40 \mathrm{~m}$ in those treated with the $6.0-\mathrm{mg} / \mathrm{kg} / \mathrm{d}$ dose. $^{26}$ Similarly, the NSAA showed an improvement of 2 to 2.5 points at 24 weeks with vamorolone treatment of 2.0 and $6.0 \mathrm{mg} / \mathrm{kg} / \mathrm{d}$, which is indicative of a functional improvement reaching or exceeding a 1-point gain for 2 clinically meaningful activities or a substantial improvement in 1 functional activity transitioning from inability to perform the activity to normal performance.

A limitation of the statistical comparison of the lowest-dose group $(0.25 \mathrm{mg} / \mathrm{kg} / \mathrm{d})$ to higher-dose groups (2.0 and 6.0 $\mathrm{mg} / \mathrm{kg} / \mathrm{d}$ ) is that the $0.25-\mathrm{mg} / \mathrm{kg} / \mathrm{d}$ group was slightly older and weaker at baseline than the other groups (table 1).

The lack of deleterious changes in bone turnover markers in patients with DMD treated with vamorolone suggests a possible loss of bone morbidities typically associated with glucocorticoids. Glucocorticoid treatment is the most common cause of osteoporosis; fractures occur in $30 \%$ to $50 \%$ of patients with DMD receiving long-term therapy. ${ }^{27}$ A recent retrospective study of an inception cohort of 403,337 patients newly diagnosed with rheumatoid arthritis, asthma/chronic obstructive pulmonary disease, inflammatory bowel disease, multiple sclerosis, lupus, and sarcoidosis found $72 \%$ to be prescribed glucocorticoids ( $52 \%$ at age $<50$ years). ${ }^{28}$ Use of glucocorticoids was strongly associated with increased rate of fractures, with greatest risk at doses of prednisone $\geq 15 \mathrm{mg} / \mathrm{d}$. A $35-\mathrm{kg}$ boy with DMD taking $0.75 \mathrm{mg} / \mathrm{kg} / \mathrm{d}$ prednisone or $0.9 \mathrm{mg} / \mathrm{kg} / \mathrm{d}$ deflazacort is taking about double this "high risk" dose ( $\approx 30 \mathrm{mg} / \mathrm{d}$ prednisone or equivalent). Serum osteocalcin is a robust biomarker of bone formation and bone turnover in children that is central to growth. ${ }^{29}$ Increases in serum osteocalcin have been shown to predict improvements in bone density and bone geometry. ${ }^{30}$ Both deflazacort and prednisone significantly reduce serum osteocalcin levels. ${ }^{31,32}$ In contrast, vamorolone increased osteocalcin levels, suggesting loss of deleterious bone effects (supplemental table 10 available from Dryad, doi.org/10.5061/dryad.1rd4hc7).

A limitation of this trial is the open-label, nonrandomized, non-placebo-controlled design considered Class IV evidence. However, it is unlikely that a placebo effect resulted in the findings reported here for the following reasons. First, the study design included a 24-fold dose range of vamorolone, and all drug responsive data were found to fit dose-response curves for efficacy and safety. Second, this first-in-patient study estimated a sample size needed to detect a difference from steroid-naive patients from a natural history study ${ }^{5,19}$ and a prednisone trial ${ }^{20}$ in the same narrow age range; therefore, the study was powered for detection of both efficacy and safety outcomes with 48 patients (12 per dose group). Third, the vamorolone trial was conducted by the CINRG academic clinical trial network, which also conducted the comparator natural history and prednisone studies using similar outcome measures and training protocols for clinical evaluators. Fourth, the results for the low-dose vamorolone groups $(0.25$ and $0.75 \mathrm{mg} / \mathrm{kg} / \mathrm{d})$ were similar to results of the untreated natural history comparator group. Finally, we used multiple serum biomarkers in multiple contexts of use as objective outcome measures for both safety (bone turnover, insulin resistance, and adrenal suppression) and efficacy (exploratory pharmacodynamics). ${ }^{18}$ All showed clear dose responses within this dose-ranging study. 
Of the 48 patients enrolled in this trial, 43 continue treatment through a 2-year long-term extension study with permitted dose escalation (VBP15-LTE) such that all increased to either the 2.0 - or $6.0-\mathrm{mg} / \mathrm{kg} / \mathrm{d}$ dose. Therefore, patients have $\approx 12$ months of additional high-dose drug exposure (2.0 and 6.0 $\mathrm{mg} / \mathrm{kg} / \mathrm{d}$ ) at the time of writing. Such longer-term studies may enable better assessments of glucocorticoid morbidities such as long bone and vertebral fractures, stunting of growth, and delayed puberty.

A double blind, placebo-controlled clinical trial of vamorolone is currently underway (VBP15-004; NCT03439670). This trial is testing 2 doses of vamorolone $(2.0$ and $6.0 \mathrm{mg} / \mathrm{kg} / \mathrm{d})$ vs placebo and prednisone $(0.75 \mathrm{mg} / \mathrm{kg} / \mathrm{d})$ and is enrolling 120 patients (30 per arm) with the same inclusion criteria as the exploratory dose-ranging study described in this report. This ongoing study is designed to provide a higher level of evidence for the efficacy and comparative safety of vamorolone in DMD.

A novel dissociative steroidal anti-inflammatory drug, vamorolone, showed evidence of efficacy and reduction of safety concerns typically seen with traditional glucocorticoids in a 48-patient, open-label, exploratory, multiple-ascendingdose study in young patients with DMD.

\section{Study funding}

ReveraGen BioPharma was the drug sponsor and received funds to carry out the described clinical trial from Actelion Pharmaceuticals (option agreement), US and EU governments, and nonprofit foundations. This work was funded by $\mathrm{NIH}$ (United States) grants (National Institutes of Neurologic Disorders and Stroke R44NS095423 [E.P.H., P.R.C.], National Institute of Child Health and Human Development 5U54HD090254 [J.v.d.A., E.P.H., L.S.C.], and a European Commission Horizons 2020 (grant agreement 667078; M.G.). Support for the vamorolone development program was provided by the Muscular Dystrophy Association (United States), Foundation to Eradicate Duchenne (United States), Parent Project Muscular Dystrophy (United States), DuchenneUK (Joining Jack [United Kingdom], Duchenne Children's Trust [United Kingdom]), Duchenne Research Fund (United Kingdom), Save Our Sons (Australia), Michael's Cause (United States), Pietro's Fight (United States), Alex's Wish (United Kingdom), Ryan's Quest (United States), and CureDuchenne (United States). Vamorolone was developed through a partnership with the NIH National Center for Advancing Translational Sciences Therapeutics for Rare and Neglected Diseases program, with support for drug production, formulation, and toxicology studies. The CINRG DNHS was supported by US Department of Education/ National Institute on Disability, Independent Living, and Rehabilitation Research (H133B031118, H133B090001); US Department of Defense (W81XWH-12-1-0417); NIH/ National Institute of Arthritis and Musculoskeletal and Skin Diseases (R01AR061875); and Parent Project Muscular Dystrophy. The authors thank the CINRG and study participants for their role in the CINRG DNHS and Prednisone Clinical Trial used as external comparator data. Patents awarded relevant to the results include WO2017004205 (A1), US2016060289 (A1), US2015011519 (A1), US9649320 (B2), and US2017027959 (A1).

\section{Disclosure}

E. Hoffman is a board member, shareholder, and chief executive officer of ReveraGen BioPharma; a board member and shareholder of TRiNDS LLC; and a cofounder of ReveraGen and owns founder shares. B. Schwartz and L. Mengle-Gaw received support from ReveraGen BioPharma and own Camden Group, LLC, a clinical research organization. E. Smith, D. Castro, J. Mah, C. McDonald, N. Kuntz, R. Finkel, M. Guglieri, K. Bushby, M. Tulinius, Y. Nevo, M. Ryan, and R. Webster received support from ReveraGen BioPharma. A. Smith, L. Morgenroth, A. Arrieta, and M. Shimony are employed by TRiNDS LLC. C. Siener received support from ReveraGen BioPharma. M. Jaros and P. Shale received support from ReveraGen BioPharma and are employees of Summit Analytical, a biostatistics clinical research organization. J. McCall and $\mathrm{K}$. Nagaraju are board members, shareholders, and vice presidents of ReveraGen BioPharma and cofounders of ReveraGen and own founder shares. J. van den Anker and L. Conklin are employed by ReveraGen BioPharma and hold stock options. A. Cnaan and H. Gordish-Dressman are shareholders of TRiNDS LLC. J. Damsker is employed by ReveraGen BioPharma and holds stock options. P. Clemens is a board member of TRiNDS LLC and received support from ReveraGen BioPharma. Go to Neurology.org/N for full disclosures.

\section{Publication history}

Received by Neurology October 26, 2018. Accepted in final form May 29, 2019.

\begin{tabular}{|c|c|c|c|}
\hline Name & Location & Role & Contribution \\
\hline $\begin{array}{l}\text { Eric P. } \\
\text { Hoffman, } \\
\text { PhD }\end{array}$ & $\begin{array}{l}\text { ReveraGen } \\
\text { BioPharma, } \\
\text { Rockville, MD }\end{array}$ & Author & $\begin{array}{l}\text { Designed and } \\
\text { conceptualized study; } \\
\text { analyzed the data; } \\
\text { drafted the manuscript } \\
\text { for intellectual content }\end{array}$ \\
\hline $\begin{array}{l}\text { Benjamin D. } \\
\text { Schwartz, MD }\end{array}$ & $\begin{array}{l}\text { Camden Group, } \\
\text { St. Louis, MO }\end{array}$ & Author & $\begin{array}{l}\text { Medical Monitor; } \\
\text { analyzed the data; } \\
\text { revised the manuscript } \\
\text { for intellectual content }\end{array}$ \\
\hline $\begin{array}{l}\text { Laurel J. } \\
\text { Mengle-Gaw, } \\
\text { PhD }\end{array}$ & $\begin{array}{l}\text { Camden Group, } \\
\text { St. Louis, MO }\end{array}$ & Author & $\begin{array}{l}\text { Clinical Monitor; } \\
\text { analyzed the data; } \\
\text { revised the manuscript } \\
\text { for intellectual content }\end{array}$ \\
\hline $\begin{array}{l}\text { Edward C. } \\
\text { Smith, MD }\end{array}$ & $\begin{array}{l}\text { Duke University, } \\
\text { Durham, NC }\end{array}$ & Author & $\begin{array}{l}\text { Recruited and followed } \\
\text { up patients; revised the } \\
\text { manuscript for } \\
\text { intellectual content }\end{array}$ \\
\hline $\begin{array}{l}\text { Diana Castro, } \\
\text { MD }\end{array}$ & $\begin{array}{l}\text { University of } \\
\text { Texas } \\
\text { Southwestern, } \\
\text { Dallas }\end{array}$ & Author & $\begin{array}{l}\text { Recruited and followed } \\
\text { up patients; revised the } \\
\text { manuscript for } \\
\text { intellectual content }\end{array}$ \\
\hline
\end{tabular}


Appendix (continued)

\begin{tabular}{|c|c|c|c|}
\hline Name & Location & Role & Contribution \\
\hline $\begin{array}{l}\text { Jean K. Mah, } \\
\text { MD }\end{array}$ & $\begin{array}{l}\text { Alberta Children's } \\
\text { Hospital, Calgary, } \\
\text { Canada }\end{array}$ & Author & $\begin{array}{l}\text { Recruited and followed } \\
\text { up patients; revised the } \\
\text { manuscript for } \\
\text { intellectual content }\end{array}$ \\
\hline
\end{tabular}

\begin{tabular}{llll}
\hline Craig M. & University of & Author & Recruited and followed \\
McDonald, & California Davis, & & $\begin{array}{l}\text { up patients; revised the } \\
\text { manuscript for }\end{array}$ \\
MD & Sacramento & & intellectul content
\end{tabular}

Nancy L. Ann \& Robert H. Author Recruited and followed
Hospital, Chicago, IL manuscript for intellectual content

\begin{tabular}{|c|c|c|c|}
\hline $\begin{array}{l}\text { Richard S. } \\
\text { Finkel, MD }\end{array}$ & $\begin{array}{l}\text { Nemours } \\
\text { Children's } \\
\text { Hospital, } \\
\text { Orlando, FL }\end{array}$ & Author & $\begin{array}{l}\text { Recruited and followed } \\
\text { up patients; revised the } \\
\text { manuscript for } \\
\text { intellectual content }\end{array}$ \\
\hline $\begin{array}{l}\text { Michela } \\
\text { Guglieri, MD }\end{array}$ & $\begin{array}{l}\text { Newcastle } \\
\text { University, } \\
\text { Newcastle-Upon- } \\
\text { Tyne, UK }\end{array}$ & Author & $\begin{array}{l}\text { Designed and } \\
\text { conceptualized study; } \\
\text { recruited and followed } \\
\text { up patients; revised the } \\
\text { manuscript for } \\
\text { intellectual content }\end{array}$ \\
\hline $\begin{array}{l}\text { Katharine } \\
\text { Bushby, MD }\end{array}$ & $\begin{array}{l}\text { Newcastle } \\
\text { University, } \\
\text { Newcastle-Upon- } \\
\text { Tyne, UK }\end{array}$ & Author & $\begin{array}{l}\text { Designed and } \\
\text { conceptualized study; } \\
\text { revised the manuscript } \\
\text { for intellectual content }\end{array}$ \\
\hline $\begin{array}{l}\text { Mar Tulinius, } \\
\text { MD }\end{array}$ & $\begin{array}{l}\text { Queen Silvia } \\
\text { Children's Hospital, } \\
\text { Gothenburg, } \\
\text { Sweden }\end{array}$ & Author & $\begin{array}{l}\text { Recruited and followed } \\
\text { up patients; revised the } \\
\text { manuscript for } \\
\text { intellectual content }\end{array}$ \\
\hline $\begin{array}{l}\text { Yoram Nevo, } \\
\text { MD }\end{array}$ & $\begin{array}{l}\text { Schneider } \\
\text { Children's } \\
\text { Medical Center, } \\
\text { Tel Aviv, Israel }\end{array}$ & Author & $\begin{array}{l}\text { Recruited and followed } \\
\text { up patients; revised the } \\
\text { manuscript for } \\
\text { intellectual content }\end{array}$ \\
\hline $\begin{array}{l}\text { Monique M. } \\
\text { Ryan, MD }\end{array}$ & $\begin{array}{l}\text { Royal Children's } \\
\text { Hospital, } \\
\text { Melbourne, } \\
\text { Australia }\end{array}$ & Author & $\begin{array}{l}\text { Recruited and followed } \\
\text { up patients; revised the } \\
\text { manuscript for } \\
\text { intellectual content }\end{array}$ \\
\hline $\begin{array}{l}\text { Richard } \\
\text { Webster, MD }\end{array}$ & $\begin{array}{l}\text { The Children's } \\
\text { Hospital at } \\
\text { Westmead, } \\
\text { Sydney, Australia }\end{array}$ & Author & $\begin{array}{l}\text { Recruited and followed } \\
\text { up patients; revised the } \\
\text { manuscript for } \\
\text { intellectual content }\end{array}$ \\
\hline $\begin{array}{l}\text { Andrea L. } \\
\text { Smith, MS }\end{array}$ & $\begin{array}{l}\text { TRiNDS, } \\
\text { Kensington, MD }\end{array}$ & Author & $\begin{array}{l}\text { Managed study; revised } \\
\text { the manuscript for } \\
\text { intellectual content }\end{array}$ \\
\hline $\begin{array}{l}\text { Lauren P. } \\
\text { Morgenroth, } \\
\text { MS }\end{array}$ & $\begin{array}{l}\text { TRiNDS, } \\
\text { Kensington, MD }\end{array}$ & Author & $\begin{array}{l}\text { Managed study; revised } \\
\text { the manuscript for } \\
\text { intellectual content }\end{array}$ \\
\hline $\begin{array}{l}\text { Adrienne } \\
\text { Arrieta, MS }\end{array}$ & $\begin{array}{l}\text { TRiNDS, } \\
\text { Kensington, MD }\end{array}$ & Author & $\begin{array}{l}\text { Managed study; revised } \\
\text { the manuscript for } \\
\text { intellectual content }\end{array}$ \\
\hline $\begin{array}{l}\text { Maya } \\
\text { Shimony, } \\
\text { MPH }\end{array}$ & $\begin{array}{l}\text { TRiNDS, } \\
\text { Kensington, MD }\end{array}$ & Author & $\begin{array}{l}\text { Managed study; revised } \\
\text { the manuscript for } \\
\text { intellectual content }\end{array}$ \\
\hline $\begin{array}{l}\text { Catherine } \\
\text { Siener, PT }\end{array}$ & $\begin{array}{l}\text { TRiNDS, } \\
\text { Kensington, MD }\end{array}$ & Author & $\begin{array}{l}\text { Managed study; revised } \\
\text { the manuscript for } \\
\text { intellectual content }\end{array}$ \\
\hline $\begin{array}{l}\text { Mark Jaros, } \\
\text { PhD }\end{array}$ & $\begin{array}{l}\text { Summit } \\
\text { Analytical, } \\
\text { Denver, CO }\end{array}$ & Author & $\begin{array}{l}\text { Statistical analysis of } \\
\text { data; revised the } \\
\text { manuscript for } \\
\text { intellectual content }\end{array}$ \\
\hline
\end{tabular}

Appendix (continued)

\begin{tabular}{|c|c|c|c|}
\hline Name & Location & Role & Contribution \\
\hline $\begin{array}{l}\text { Phil Shale, } \\
\text { PhD }\end{array}$ & $\begin{array}{l}\text { Summit } \\
\text { Analytical, } \\
\text { Denver, CO }\end{array}$ & Author & $\begin{array}{l}\text { Statistical analysis of } \\
\text { data; revised the } \\
\text { manuscript for } \\
\text { intellectual content }\end{array}$ \\
\hline $\begin{array}{l}\text { John M. } \\
\text { McCall, PhD }\end{array}$ & $\begin{array}{l}\text { ReveraGen } \\
\text { BioPharma, } \\
\text { Rockville, MD }\end{array}$ & Author & $\begin{array}{l}\text { Designed drug; } \\
\text { managed drug supply; } \\
\text { revised the } \\
\text { manuscript for } \\
\text { intellectual content }\end{array}$ \\
\hline $\begin{array}{l}\text { Kanneboyina } \\
\text { Nagaraju, } \\
\text { PhD, DVM }\end{array}$ & $\begin{array}{l}\text { ReveraGen } \\
\text { BioPharma, } \\
\text { Rockville, MD }\end{array}$ & Author & $\begin{array}{l}\text { Interpretation of data; } \\
\text { revised the manuscript } \\
\text { for intellectual content }\end{array}$ \\
\hline $\begin{array}{l}\text { John van den } \\
\text { Anker, MD, } \\
\text { PhD }\end{array}$ & $\begin{array}{l}\text { Children's } \\
\text { National Health } \\
\text { System, } \\
\text { Washington, DC }\end{array}$ & Author & $\begin{array}{l}\text { Interpretation of data; } \\
\text { revised the manuscript } \\
\text { for intellectual content }\end{array}$ \\
\hline $\begin{array}{l}\text { Laurie S. } \\
\text { Conklin, MD }\end{array}$ & $\begin{array}{l}\text { Children's } \\
\text { National Health } \\
\text { System, } \\
\text { Washington, DC }\end{array}$ & Author & $\begin{array}{l}\text { Interpretation of data; } \\
\text { revised the manuscript } \\
\text { for intellectual content }\end{array}$ \\
\hline $\begin{array}{l}\text { Avital Cnaan, } \\
\text { PhD }\end{array}$ & $\begin{array}{l}\text { TRiNDS, } \\
\text { Kensington }\end{array}$ & Author & $\begin{array}{l}\text { Statistical design of } \\
\text { study; revised the } \\
\text { manuscript for } \\
\text { intellectual content }\end{array}$ \\
\hline $\begin{array}{l}\text { Heather } \\
\text { Gordish- } \\
\text { Dressman, } \\
\text { PhD }\end{array}$ & $\begin{array}{l}\text { Children's } \\
\text { National Health } \\
\text { System, } \\
\text { Washington }\end{array}$ & Author & $\begin{array}{l}\text { Statistical design of } \\
\text { study; data } \\
\text { interpretation; revised } \\
\text { the manuscript for } \\
\text { intellectual content }\end{array}$ \\
\hline $\begin{array}{l}\text { Jesse M. } \\
\text { Damsker, } \\
\text { PhD }\end{array}$ & $\begin{array}{l}\text { ReveraGen } \\
\text { BioPharma, } \\
\text { Rockville }\end{array}$ & Author & $\begin{array}{l}\text { Management of study; } \\
\text { management of } \\
\text { research pharmacies } \\
\text { and drug supply; } \\
\text { regulatory } \\
\text { management; revised } \\
\text { the manuscript for } \\
\text { intellectual content }\end{array}$ \\
\hline $\begin{array}{l}\text { Paula R. } \\
\text { Clemens, MD }\end{array}$ & $\begin{array}{l}\text { University of } \\
\text { Pittsburgh, } \\
\text { Pittsburgh }\end{array}$ & Author & $\begin{array}{l}\text { Study Chair; design of } \\
\text { study; data } \\
\text { interpretation; revised } \\
\text { the manuscript for } \\
\text { intellectual content }\end{array}$ \\
\hline
\end{tabular}

\section{References}

1. Hench PS, Kendall EC, Slocumb CH, Polley HF. The effect of a hormone of the adrenal cortex (17-hydroxy-11-dehydrocorticosterone: compound E) and of pituitary adrenocortical hormone in arthritis: preliminary report. Ann Rheum Dis 1949;8:97-104.

2. The Nobel Prize in Physiology or Medicine 1950.Nobelprize.org. Nobel Media AB. 2014. Available at: nobelprize.org/nobel_prizes/medicine/laureates/1950/. Accessed May 27, 2018.

3. Hoffman EP, Brown RH Jr, Kunkel LM. Dystrophin: the protein product of the Duchenne muscular dystrophy locus. Cell 1987;51:919-928.

4. Guglieri M, Bushby K, McDermott MP, et al. Developing standardized corticosteroid treatment for Duchenne muscular dystrophy. Contemp Clin Trials 2017;58:34-39.

5. McDonald CM, Henricson EK, Abresch RT, et al. Long-term effects of glucocorticoids on function, quality of life, and survival in patients with Duchenne muscular dystrophy: a prospective cohort study. Lancet 2018;391:451-461.

6. Chen YW, Nagaraju K, Bakay M, et al. Early onset of inflammation and later involvement of TGFbeta in Duchenne muscular dystrophy. Neurology 2005;65:826-834.

7. Rosenberg AS, Puig M, Nagaraju K, et al. Immune-mediated pathology in Duchenne muscular dystrophy. Sci Transl Med 2015;7:299rv4.

8. Reeves EKM, Hoffman EP, Nagaraju K, Damsker JM, McCall JM. VBP15: preclinical characterization of a novel anti-inflammatory delta 9,11 steroid. Bioorg Med Chem 2013;21:2241-2249.

9. Clark AR, Belvisi MG. Maps and legends: the quest for dissociated ligands of the glucocorticoid receptor. Pharmacol Ther 2012;134:54-67. 
10. Heier CR, Damsker JM, Yu Q, et al. VBP15, a novel anti-inflammatory and membrane-stabilizer, improves muscular dystrophy without side effects. EMBO Mol Med 2013;5:1569-1585.

11. Fiorillo AA, Tully CB, Damsker JM, Nagaraju K, Hoffman EP, Heier CR. Muscle miRNAome shows suppression of chronic inflammatory miRNAs with both prednisone and vamorolone. Physiol Genomics 2018;50:735-745

12. Sreetama SC, Chandra G, Van der Meulen JH, et al. Membrane stabilization by modified steroid offers a potential therapy for muscular dystrophy due to dysferlin deficit. Mol Ther 2018;26:2231-2242.

13. Heier CR, Yu Q, Fiorillo AA, et al. Vamorolone targets dual nuclear receptors to treat inflammation and dystrophic cardiomyopathy. Life Sci Alliance 2019;2:1.

14. Dillingham BC, Knoblach SM, Many GM, et al. VBP15, a novel anti-inflammatory, is effective at reducing the severity of murine experimental autoimmune encephalomyelitis. Cell Mol Neurobiol 2015;35:377-387.

15. Damsker JM, Dillingham BC, Rose MC, et al. VBP15, a glucocorticoid analogue, is effective at reducing allergic lung inflammation in mice. PLoS One 2013;8:e63871.

16. Damsker JM, Conklin LS, Sadri S, et al. VBP15, a novel dissociative steroid compound, reduces NFkB-induced expression of inflammatory cytokines in vitro and symptoms of murine trinitrobenzene sulfonic acid-induced colitis. Inflamm Res 2016; 65:737-743.

17. Hudson WH, Vera IMS, Nwachukwu JC, et al. Cryptic glucocorticoid receptorbinding sites pervade genomic NF- $\mathrm{kB}$ response elements. Nat Commun 2018;9:1337.

18. Hoffman EP, Riddle V, Siegler MA, et al. Phase 1 trial of vamorolone, a first-in-class steroid, shows improvements in side effects via biomarkers bridged to clinical outcomes. Steroids 2018;134:43-52.

19. Conklin LS, Damsker JM, Hoffman EP, et al. Phase IIa trial in Duchenne muscular dystrophy shows vamorolone is a first-in-class dissociative steroidal anti-inflammatory drug. Pharmacol Res 2018;136:140-150.

20. Mavroudis PD, van den Anker J, Conklin LS, et al. Population pharmacokinetics of vamorolone (VBP15) in healthy men and boys with Duchenne muscular dystrophy. J Clin Pharmacol 2019;59:979-988.

21. McDonald CM, Henricson EK, Abresch RT, et al. The cooperative international neuromuscular research group Duchenne natural history study-a longitudinal investigation in the era of glucocorticoid therapy: design of protocol and the methods used. Muscle Nerve 2013;48:32-54.

22. Escolar DM, Hache LP, Clemens PR, et al. Randomized, blinded trial of weekend vs daily prednisone in Duchenne muscular dystrophy. Neurology 2011;77: 444-452.

23. Brooke MH, Griggs RC, Mendell JR, Fenichel GM, Shumate JB, Pellegrino RJ. Clinical trial in Duchenne dystrophy, I: the design of the protocol. Muscle Nerve 1981;4:186-197.

24. McDonald CM, Henricson EK, Han JJ, et al. The 6-minute walk test as a new outcome measure in Duchenne muscular dystrophy. Muscle Nerve 2009;41:500-510.

25. Scott E, Eagle M, Mayhew A, et al. Development of a functional assessment scale for ambulatory boys with Duchenne muscular dystrophy. Physiother Res Int 2012;17: 101-109.

26. Henricson E, Abresch R, Han JJ, et al. The 6-minute walk test and person-reported outcomes in boys with Duchenne muscular dystrophy and typically developing controls: longitudinal comparisons and clinically-meaningful changes over one year. 2013 Jul 8. doi: 10.1371/currents.md.9e17658b007eb79fcd6f723089f79e06.

27. Weinstein RS. Clinical practice: glucocorticoid-induced bone disease. N Engl J Med 2011;365:62-70.

28. Balasubramanian A, Wade SW, Adler RA, Saag K, Pannacciulli N, Curtis JR. Glucocorticoid exposure and fracture risk in a cohort of US patients with selected conditions. J Bone Miner Res 2018;33:1881-1888.

29. Szulc P, Seeman E, Delmas PD. Biochemical measurements of bone turnover in children and adolescents. Osteoporos Int 2000;11:281-294.

30. Pye SR, Ward KA, Cook MJ, et al. Bone turnover predicts change in volumetric bone density and bone geometry at the radius in men. Osteoporos Int 2017;28:935-944.

31. Babadjanova G, Allolio B, Vollmer M, Reincke M, Schulte HM. Comparison of the pharmacodynamic effects of deflazacort and prednisolone in healthy subjects. Eur J Clin Pharmacol 1996;51:53-57.

32. Saviola G, Abdi Ali L, Shams Eddin S, et al. Compared clinical efficacy and bone metabolic effects of low-dose deflazacort and methyl prednisolone in male inflammatory arthropathies: a 12-month open randomized pilot study. Rheumatology (Oxford) 2007;46:994-998. 


\section{Neurology}

\section{Vamorolone trial in Duchenne muscular dystrophy shows dose-related improvement of muscle function}

Eric P. Hoffman, Benjamin D. Schwartz, Laurel J. Mengle-Gaw, et al.

Neurology 2019;93;e1312-e1323 Published Online before print August 26, 2019

DOI 10.1212/WNL.0000000000008168

This information is current as of August 26, 2019

Updated Information \&

Services

References

Subspecialty Collections

Permissions \& Licensing

Reprints including high resolution figures, can be found at: http://n.neurology.org/content/93/13/e1312.full

This article cites 30 articles, 5 of which you can access for free at: http://n.neurology.org/content/93/13/e1312.full\#ref-list-1

This article, along with others on similar topics, appears in the following collection(s):

\section{Class IV}

http://n.neurology.org/cgi/collection/class_iv

Clinical trials Observational study (Cohort, Case control)

http://n.neurology.org/cgi/collection/clinical_trials_observational_stud y_cohort_case_control

Muscle disease

http://n.neurology.org/cgi/collection/muscle_disease

Information about reproducing this article in parts (figures,tables) or in its entirety can be found online at:

http://www.neurology.org/about/about_the_journal\#permissions

Information about ordering reprints can be found online:

http://n.neurology.org/subscribers/advertise

Neurology ${ }^{\circledR}$ is the official journal of the American Academy of Neurology. Published continuously since 1951, it is now a weekly with 48 issues per year. Copyright Copyright (C) 2019 The Author(s). Published by Wolters Kluwer Health, Inc. on behalf of the American Academy of Neurology.. All rights reserved. Print ISSN: 0028-3878. Online ISSN: 1526-632X.

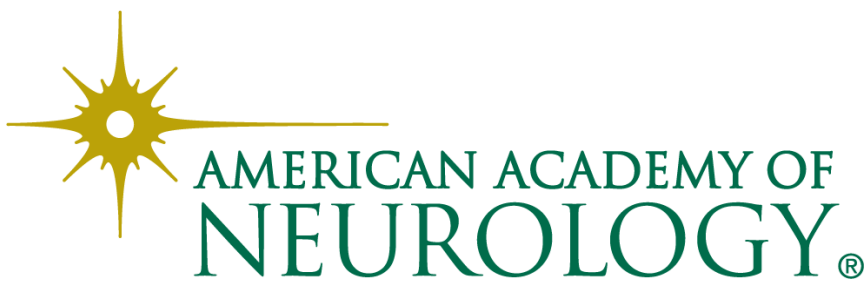

